Case Reports
in Dermatology

\title{
Schwannoma of the Lower Lip: A Case Report of an Unusual Presentation
}

\author{
Ghadah Alhammad $^{\mathrm{a}} \quad$ Alaa Alsaad $^{\mathrm{a}}$ Tariq Aljohani ${ }^{\mathrm{b}}$ \\ Abdulmajeed Alajlan ${ }^{\mathrm{a}}$ \\ aDermatology Department, College of Medicine and University Hospitals, King Saud \\ University, Riyadh, Saudi Arabia; ${ }^{b}$ Department of Pathology, College of Medicine, King \\ Saud University, Riyadh, Saudi Arabia
}

\section{Keywords}

Schwannoma $\cdot$ Neurilemmoma $\cdot$ Lower lip

\section{Abstract}

Schwannoma is a benign neoplasm that originates from the neural sheath of Schwann cells. Although extracranial schwannomas are commonly observed in the head and neck region, only $1 \%$ are found in the intraoral cavity. This article describes the first case in the Eastern Mediterranean region of a lower lip schwannoma in a 17-year-old male patient.

(C) 2021 The Author(s)

Published by S. Karger AG, Basel

\section{Introduction}

Schwannoma, which is also called neurilemmoma, is a rare benign tumor with unknown etiology that is formed entirely from neural sheath Schwann cells [1]. Among all schwannomas, $25-40 \%$ are found in the soft tissues of the head and neck region, but they are uncommonly located in the oral cavity, and the lips are the rarest site of involvement [2]. Therefore, lip schwannomas are often underrecognized in the initial differential diagnosis [2]. Here, we present the first case in the Eastern Mediterranean region of a 17-year-old male patient with schwannoma in the lower lip mucosa that had been slowly growing for 1 year. 


\section{Case Reports in Dermatology}

Case Rep Dermatol 2021;13:164-170

DOI: $10.1159 / 000513568$

(c) 2021 The Author(s). Published by S. Karger AG, Basel www.karger.com/cde

Alhammad et al.: Schwannoma of the Lower Lip

\section{Case Report}

A 17-year-old male patient presented in June 2020 to our dermatology clinic with a painless slow-growing swelling on the left lower lip. The patient reported that the swelling had started without any predisposing cause such as trauma around 1 year before presentation. The patient was a nonsmoker and had no significant medical history

Intraoral examination revealed a solitary, soft, mobile, nonulcerated, nontender, multilobulated nodule that measured approximately $2 \times 3 \mathrm{~cm}$ over the left side of the lower vermilion lip with normal-appearing overlying mucosa (Fig. 1). Differential diagnoses were mucocele, fibroma, monomorphic adenoma, oral nodular fasciitis, dermoid cyst, schwannoma, palisading encapsulated neuroma, lipoma, and squamous cell carcinoma. An excisional biopsy was performed under local anesthesia (Fig. 2) and the surgical specimen was sent for histological staining and examination. At a follow-up visit 2 weeks later, the sutures were removed and the postoperative recovery was uneventful.

Histopathologic analysis demonstrated a well-circumscribed, encapsulated tumor with hypercellular and hypocellular (Antoni A, B-type tissue, respectively) areas. The hypercellular areas showed proliferation of spindle cells, and nuclear palisading "Verocay bodies" were observed (Fig. 3). Staining for S100 protein in immunohistochemistry was strongly positive (Fig. 4). The diagnosis was consistent with schwannoma.

\section{Discussion}

Schwannoma is a benign, asymptomatic, slow-growing, usually solitary tumor that can arise from Schwann cells of the cranial, peripheral, or autonomic nerve sheath [3]. It was first reported by Verocay in 1908 and was termed neurinoma [4]. Schwannoma can affect males and females equally in any age group, with a higher incidence in the fourth decade of life [5, 6]. In the literature, schwannoma of the lower lips has rarely been reported [2]. This case is the first case of lower lip schwannoma to be reported in the Eastern Mediterranean region.

Histopathologically, schwannoma is usually encapsulated and exhibits proliferation of spindle-shaped cells that are categorized into two histological patterns, Antoni type A and Antoni type $B$ arrangements, with alternating areas of hypercellularity and hypocellularity $[5,6]$. These typical histopathological findings along with S100 protein-positive immunohistochemistry results are used to confirm the diagnosis [7].

Treatment of schwannomas usually consists of conservative surgical tumor removal [8]. The prognosis is quite favorable, and malignant transformation has not been found. Recurrence is rare after successful tumor resection [9].

In conclusion, we have described a rare presentation of schwannoma in the lower lip, and we propose that patients with this lesion type have an excellent prognosis if it is recognized early and managed promptly. Therefore, it must be included in the initial differential diagnosis when evaluating a patient with a painless lip swelling.

\section{Karger'=}




\section{Case Reports in Dermatology}

\section{Statement of Ethics}

This work was conducted ethically in accordance with the World Medical Association Declaration of Helsinki. Written informed consent was obtained from the patient for publication of this case report and accompanying images.

\section{Conflict of Interest Statement}

The authors have no conflicts of interest to declare.

\section{Funding Sources}

There were no funding sources for this work.

\section{Author Contributions}

G. Alhammad, A. Alsaad, and A. Alajlan: case diagnosis, manuscript drafting, manuscript revision, and final approval of the work to be published. T. Aljohani: histopathological analysis, manuscript drafting, manuscript revision, and final approval of the work to be published.

\section{References}

1 Sitenga JL, Aird GA, Nguyen A, Vaudreuil A, Huerter C. Clinical Features and Surgical Treatment of Schwannoma Affecting the Base of the Tongue: A Systematic Review. Int Arch Otorhinolaryngol. 2017 Oct;21(4):408-13.

2 Sitenga J, Aird G, Vaudreuil A, Huerter CJ. Clinical features and management of schwannoma affecting the upper and lower lips. Int J Dermatol. 2018 Sep;57(9):1047-52.

3 Cohen M, Wang MB. Schwannoma of the tongue: two case reports and review of the literature. Eur Arch Otorhinolaryngol. 2009 Nov;266(11):1823-9.

4 Krishnan B, Basu D, Daniel JM. A discrete swelling of the upper lip: a diagnostic and clinical stepladder. J Maxillofac Oral Surg. 2014 Sep;13(3):300-4.

5 da Silva LF, Duarte BG, Boiça BA, Rocha-Junior HV, Pereira-Stabile CL. Intraoral schwannoma: a case report. Oral Maxillofac Surg. 2013 Dec;17(4):319-21.

6 Hajong R, Hajong D, Naku N, Sharma G, Boruah M. Schwannoma of Upper Lip: Report of a Rare Case in a Rare Age Group. J Clin Diagn Res. 2016 Aug;10(8):PD10-1.

7 Upadhyay S, Bhavthankar J, Mandale M, Humbe J. A diagnosis of an unusual lower lip swelling: schwannoma. Niger Postgrad Med J. 2017 Jul-Sep;24(3):191-3.

8 Humber CC, Copete MA, Hohn FI. Ancient schwannoma of upper lip: case report with distinct histologic features and review of the literature. J Oral Maxillofac Surg. 2011 Jun;69(6):e118-22.

9 Cardoso CL, Tolentino ES, Capelozza AL, Consolaro A. Schwannoma in the lower lip mucosa: unexpected diagnosis. Quintessence Int. 2010 Oct;41(9):769-71. 


\section{Case Reports in Dermatology}

(c) 2021 The Author(s). Published by S. Karger AG, Basel www.karger.com/cde

Alhammad et al.: Schwannoma of the Lower Lip

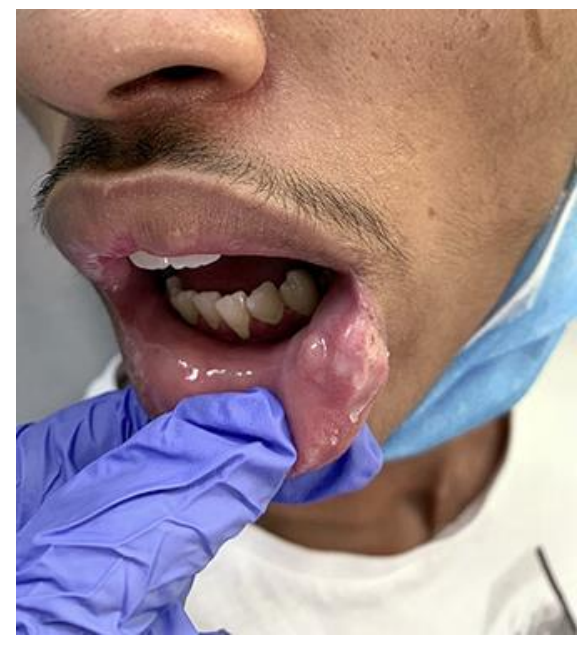

Fig. 1. Intraoral image showing $2 \times 3 \mathrm{~cm}$ soft tissue swelling with normal overlying mucosa over the lower lip. 


\section{Case Reports in Dermatology}

\begin{tabular}{l|l}
\hline Case Rep Dermatol 2021;13:164-170 \\
\hline DOI: 10.1159/000513568 & $\begin{array}{l}\text { (c) 2021 The Author(s). Published by S. Karger AG, Basel } \\
\text { www.karger.com/cde }\end{array}$ \\
\hline
\end{tabular}

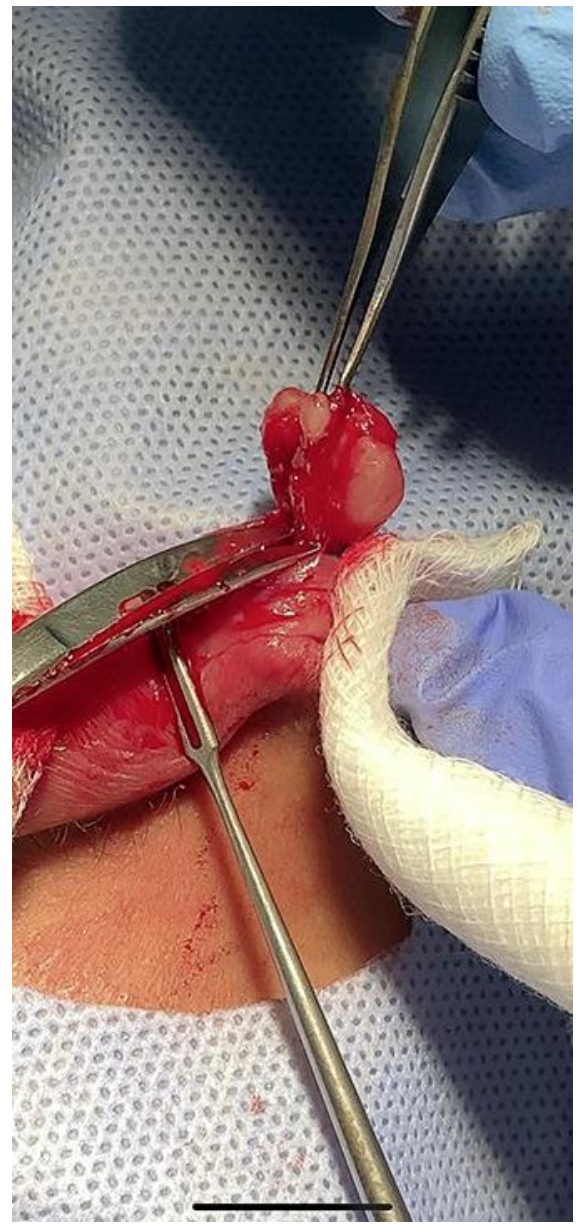

Fig. 2. Intraoperative image showing excised lesion. 


\section{Case Reports in Dermatology}

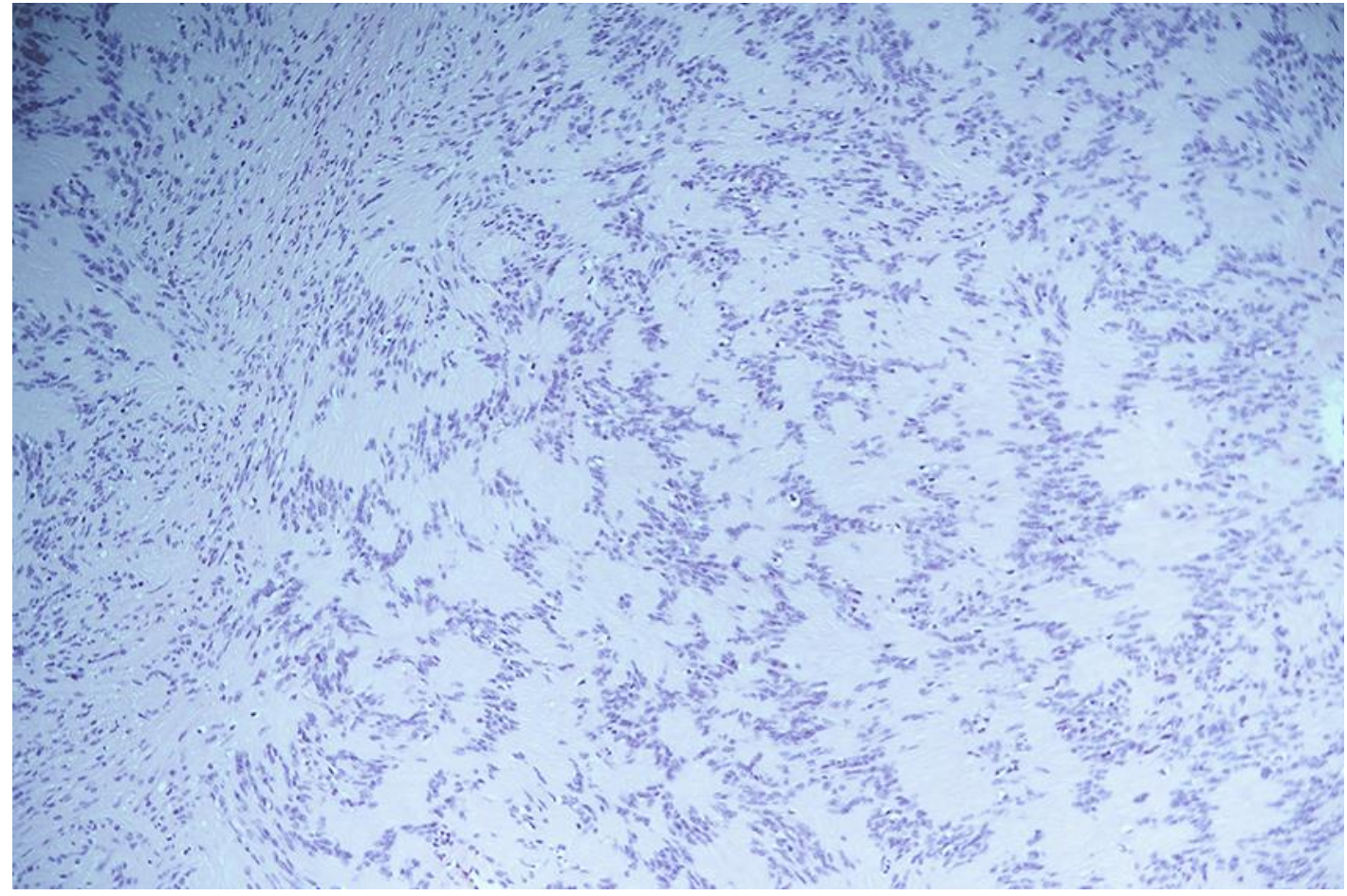

Fig. 3. H\&E stain. Biphasic: compact hypercellular Antoni A areas and myxoid hypocellular Antoni B areas with Verocay bodies in cellular areas. $\times 10$ and $\times 20$. 
Case Reports
in Dermatology

Case Rep Dermatol 2021;13:164-170

DOI: $10.1159 / 000513568$

(c) 2021 The Author(s). Published by S. Karger AG, Basel

Alhammad et al.: Schwannoma of the Lower Lip

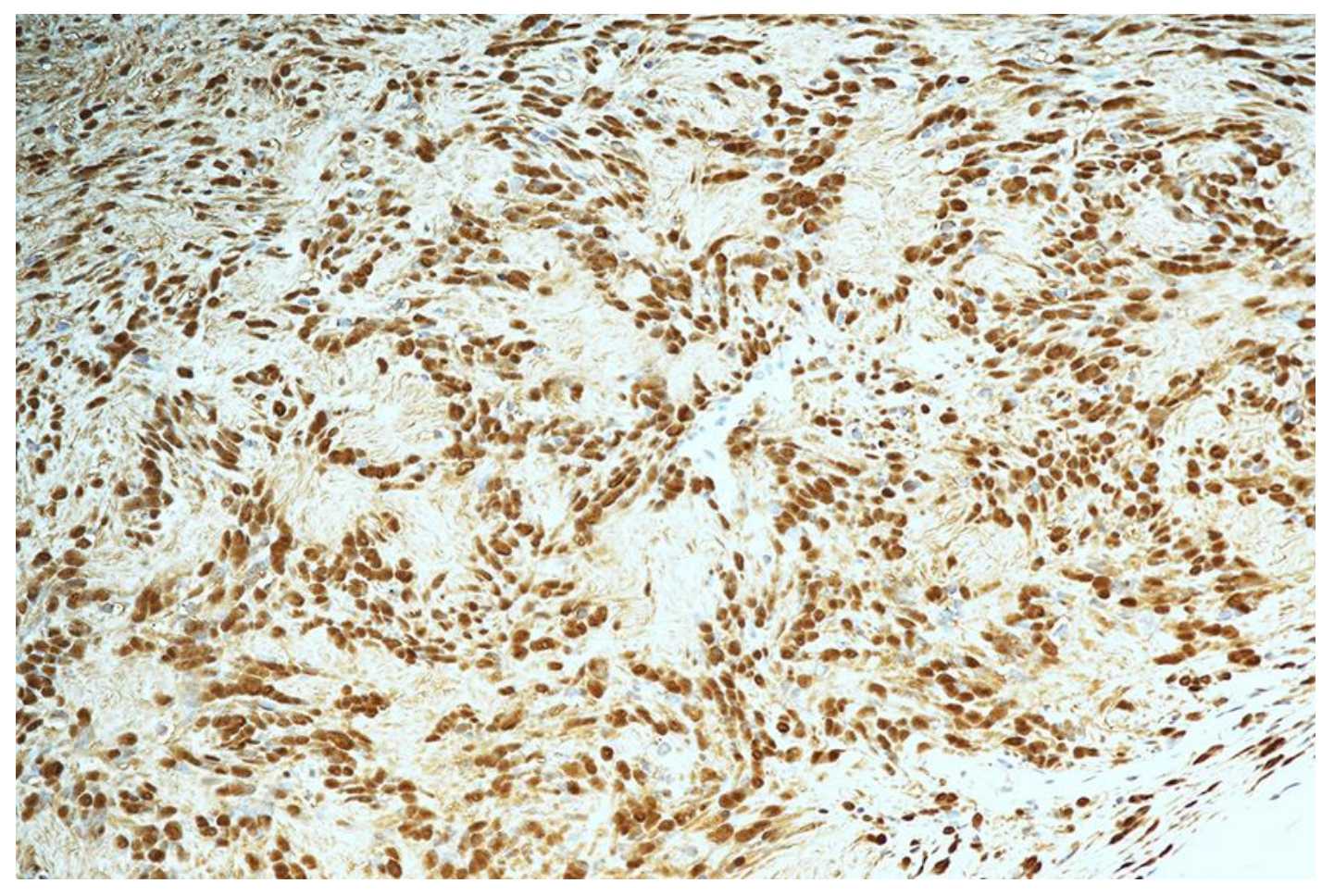

Fig. 4. Immunohistochemical stains. S100 protein strong and diffuse staining. $\times 20$.

\section{Karger'}

